\title{
Long-term Pattern and Magnitude of Soil Carbon Feedback to the Climate System in a Warming World
}

\author{
Authors: J.M. Melillo' ${ }^{1 *}$, S.D. Frey ${ }^{2}$, K.M. DeAngelis ${ }^{3}$, W.J. Werner ${ }^{1}$, M.J. Bernard ${ }^{1}$, F.P. \\ Bowles $^{4}$, G. Pold ${ }^{5}$, M.A. Knorr ${ }^{2}$, A.S. Grandy ${ }^{2}$
}

\author{
Affiliations: \\ ${ }^{1}$ The Ecosystems Center, Marine Biological Laboratory, Woods Hole, MA 02543, USA \\ ${ }^{2}$ Department of Natural Resources and the Environment, University of New Hampshire, Durham, \\ NH 03824, USA \\ ${ }^{3}$ Department of Microbiology, University of Massachusetts, Amherst, MA 01003, USA \\ ${ }^{4}$ Research Designs, Lyme, NH 03768, USA \\ ${ }^{5}$ Graduate Program in Organismic and Evolutionary Biology, University of Massachusetts, \\ Amherst, MA 01003, USA \\ *Correspondence to: jmelillo@mbl.edu
}

Abstract: In a 26-year soil warming experiment in a mid-latitude hardwood forest, we documented changes in soil carbon cycling to investigate the potential consequences for the climate system. We found that soil warming results in a four-phase pattern of soil organic matter decay and carbon dioxide fluxes to the atmosphere, with phases of substantial soil carbon loss alternating with phases of no detectable loss. Several factors combine to affect the timing, magnitude, and thermal acclimation of soil carbon loss. These include depletion of microbially accessible carbon pools, reductions in microbial biomass, a shift in microbial carbon use efficiency, and changes in microbial community composition. Our results support projections of a long-term, self-reinforcing carbon feedback from mid-latitude forests to the climate system as the world warms.

One Sentence Summary: A 26-year soil warming experiment supports projections of a longterm, self-reinforcing carbon feedback from forest soils to the climate system.

Main Text: A large and poorly understood component of global warming is the terrestrial carbon cycle feedback to the climate system (1). Simulation experiments with fully 
coupled, three-dimensional carbon-climate models suggest that carbon cycle feedbacks could substantially accelerate or slow climate change over the 21 st century (2-4). Both the sign and magnitude of these feedbacks in the real Earth system are still highly uncertain because of gaps in basic understanding of terrestrial ecosystem processes. For example, the potential switch of the terrestrial biosphere from its current role as a carbon sink to a carbon source is critically dependent on the long-term temperature sensitivity of soil organic matter (SOM) decay (5-7) and complex carbon-nitrogen interactions that will likely occur in a warmer world (8-12). However, without long-term field-based experiments, the sign of the feedback cannot be determined, the complex mechanisms regulating that feedback cannot be quantified, and models that incorporate the soil's role in carbon feedbacks to the climate system cannot be tested.

Here, we present results from a long-term (26-year) soil-warming experiment designed to explore these feedback issues in an ecosystem context. We started our soil warming study in 1991 in an even-aged mixed hardwood forest stand at the Harvard Forest in central Massachusetts $\left(42.54^{\circ} \mathrm{N}, 72.18^{\circ} \mathrm{W}\right)$, where the dominant tree species are red maple (Acer rubrum L.) and black oak (Quercus velutina Lam.). The soil is a stony loam with a distinct organic matter-rich forest floor. (See the supplementary materials for more information on the site's soils, climate, and land-use history.)

The field manipulation contains 18 plots, each $6 \times 6 \mathrm{~m}$, that are grouped into six blocks. The three plots within each block are randomly assigned to one of three treatments: (i) heated plots in which the average soil temperature is continuously elevated $5^{\circ} \mathrm{C}$ above ambient by the use of buried heating cables; (ii) disturbance control plots that are identical to the heated plots except that they receive no electrical power; and (iii) undisturbed control plots that have been left in their natural state (no cables). The heating method works well under a variety of moisture and temperature conditions (13). Here, we compared carbon dynamics measured in the heated plots to those measured in the disturbance control plots, so as to isolate heating effects from the effects of cable installation (e.g., root cutting and soil compaction) (14).

We used a static chamber technique (14) to measure soil $\mathrm{CO} 2$ emission rates in the study plots monthly between April and November each year for 26 years (see supplementary materials). An ephemeral but significant soil respiration response to warming occurred over the experiment's first decade (Fig. 1), with soil respiration greater in the heated plots than in the 
controls (phase I). In the next phase of the response, phase II (years 11 to 17), soil respiration rates in the heated plots were generally equal to or less than those in the control plots. During years 18 to 23 of the study (phase III), we observed a second trend reversal, with soil respiration once again higher in the heated plots. In the three most recent years (phase IV) of the study, 2014 to 2016, soil respiration rates in the heated plots were again equal to or less than those in the control plots.

We partitioned soil respiration into its two components, root and microbial respiration. On the basis of field measurements of root respiration made between June and November 2009, we developed a temperature-driven root respiration model that we used to estimate root respiration over the course of the experiment (see supplementary materials). We calculated microbial respiration by difference, with microbial respiration equaling soil respiration minus root respiration (10). Our estimate is that two-thirds of the cumulative $\mathrm{CO} 2-\mathrm{C}$ emitted from the plots over the 26-year study has been microbial. By this analysis, we calculate a warminginduced soil carbon loss from the full soil profile over the 26 -year study of $1510 \pm 160 \mathrm{~g} \mathrm{C} \mathrm{m}-2$, which is equivalent to a $17 \%$ loss of the soil carbon found in the top $60 \mathrm{~cm}$ of the soil at the start of the experiment. With respect to timing, we estimate that about three-quarters of this soil carbon loss occurred during phase I, and the remaining quarter during phase III. No measurable carbon loss occurred during either phase II or phase IV (Fig. 2).

In both the control and heated plots, we made direct measurements of carbon stocks in the upper horizons of the soil profile - the distinct, organic matter-rich surface horizon or forest floor and the top $30 \mathrm{~cm}$ of the mineral soil just beneath the forest floor (fig. S1). We measured a carbon loss from the forest floor in response to soil warming of $800 \pm 300 \mathrm{~g} \mathrm{C} \mathrm{m}^{-2}$, which represents a $31 \%$ reduction in forest floor carbon stock over the 26-year study. With our direct measurements, we did not detect any statistically significant changes in the carbon stocks across the top $30 \mathrm{~cm}$ of the mineral soil horizon. However, combining our estimate of carbon loss from the full profile based on the respiration measurements with the carbon loss measured from the forest floor, we estimate that the warming-induced carbon loss from the mineral soil in the full soil profile over the study period was $710 \mathrm{~g} \mathrm{C} \mathrm{m}^{-2}$. An in situ soil warming experiment in a California forest also shows that warming increases the decay of subsoil organic matter (15). 
We explored possible relationships between the multiphase pattern in soil respiration and multiyear variations in climate, and found none (see supplementary materials and fig. S2, A and B). We propose that several biogeochemical factors combine to affect the timing, magnitude, and thermal acclimation of soil carbon loss. These include depletion of microbially accessible carbon pools, reductions in microbial biomass, a shift in microbial carbon use efficiency, and changes in microbial community composition. Thermal acclimation, a phenomenon observed in response to soil warming in a grassland ecosystem (16), was evident in all four phases of our long-term soil warming experiment, such that at a given temperature there was less respiration from the heated plots than from the control plots (Fig. 3). During phases I and III, the acclimation was insufficient to compensate for the $5^{\circ} \mathrm{C}$ increase in soil temperature, so that $\mathrm{CO} 2$ emissions from heated plots were greater than from control plots. During phases II and IV, however, acclimation was large enough to compensate for the $5^{\circ} \mathrm{C}$ increase in soil temperature.

In this study, the importance of thermal acclimation of the soil respiration response became evident when power to the heated plots was off for part of the year in 1995 and 2005 and throughout 2010. The power shutdowns in 1995 and2005 resulted when summer lightning strikes damaged the system that controlled experimental heating. The power shutdown in 2010 was planned and carried out to increase our understanding of the thermal acclimation response. In the three instances, soil respiration rates in the powered down heated plots dropped below those of the controls after the power was off, and they returned (within weeks) to rates above the controls once the power was restored (fig. S3).

Our biogeochemical and molecular observations suggest that warming causes cycles of soil carbon decay punctuated by periods of structural and functional changes in the microbial community. Sustained reductions of microbial biomass over the course of the experiment [(1719) and this study] have been accompanied by several other changes, including (i) altered respiratory and lipid profiles (17); (ii) changes in microbial community structure and function as determined using small subunit ribosomal RNA analysis $(20,21)$, metagenomics (22), and enzyme assays $(19,21)$; (iii) characterization of substrate utilization profiles of bacterial isolates (22); and (iv) measurements of microbial carbon use efficiency (23).

We have integrated these observations (Table 1) to develop a conceptual model of the time-varying (four-phase) effects of soil warming on feedback to climate. Phase I was a period of 
117 substantial soil carbon loss, especially from the surface organic horizon. The rate of carbon loss 118 essentially followed an exponential decay pattern, rapid at first, slowing to near zero over the 119 experiment's first decade. In phase II, soil respiration rates in the heated plots were generally 120 equal to or less than those in the control plots. The transition from phase I to phase II was 121 characterized by a depletion of a labile C pool (18), which is considered to be the driver of 122 reduced microbial biomass (24).

123

Phase II appears to have been a period of microbial community reorganization, leading to changes in structure and function. During this time, soil heating reduced the abundance of fungal biomarkers and also caused a shift toward Gram-positive bacteria and especially actinobacteria (17). Along with these structural changes, heating reduced the capacity of microbial community to utilize simple $\mathrm{C}$ substrates (17).

The transition from phase II to phase III was characterized by a continued shift toward a more oligotrophic microbial community with increased diversity due to increased evenness (Pielou's J statistic), reduced microbial biomass, and reduced fungal dominance, as evidenced by the same population size of bacteria and narrowed fungal/bacterial ratios for $\mathrm{C}$-degrading genes (20).

In phase III, soil respiration rates were higher in the heated plots than in the controls. This third phase appears to have been a period when recalcitrant substrates such as lignin became an important source of carbon for the microbial community. This is consistent with the evidence that during phase III, relative to controls, there was an increase by a factor of 4 in potential lignin-degrading enzyme (lignase) activity in surface soils from the heated plots (21).

As phase III transitioned toward phase IV, we observed a reduction in the relative abundance of lignin in the soil C pool in the surface mineral horizon (19). At the same time, the magnitude of the carbon loss to the atmosphere through decomposition during this period may have been attenuated somewhat by a shift toward higher microbial carbon use efficiency for recalcitrant substrates in warmed soils relative to control soils (23).

Our study is just 3 years into phase IV. This new phase may turn out to be another period of microbial community reorganization that will eventually transition to yet another phase of further carbon loss from decay of recalcitrant forms of SOM. Because recalcitrant SOM pools make up a substantial fraction of global soil carbon stocks (25), small changes in the decay rates 
of these pools could result in a large self-reinforcing feedback to the climate system over multiple decades (26). As a preliminary test of global significance, extrapolating our results to the world's forests, we estimate a global aggregate soil carbon loss from the upper $1 \mathrm{~m}$ of soil (27) over the 21 st century of $\sim 190 \mathrm{Pg} \mathrm{C}$. This does not account for possible future climate-driven changes in plant-soil interactions that could affect the long term balance between the formation and decomposition of SOM. Critical to this balance will be changes in the amount of fresh carbon transferred from plants to the soils as the world warms. Inputs of this fresh carbon can contribute to soil carbon sequestration, but they can also accelerate the decomposition of more recalcitrant forms of SOM through biological priming mechanisms (28).

Our first-order estimate of a warming-induced loss of $190 \mathrm{Pg}$ of soil carbon over the $21 \mathrm{st}$ century is equivalent to the past two decades of carbon emissions from fossil fuel burning (29) and is comparable in magnitude to the cumulative carbon losses to the atmosphere due to human driven land use change during the past two centuries (30). A transfer of carbon of this magnitude from forest soils to the atmosphere in response to warming would amplify the mitigation challenge already faced by society. It is also important to recognize that a global-scale, microbially mediated feedback could be very difficult, if not impossible, to halt.

\section{References and Notes:}

1. J.G. Canadell et al. Contributions to accelerating atmospheric $\mathrm{CO} 2$ growth from economic activity, carbon intensity, and efficiency of natural sinks. Proc. Natl. Acad. Sci. U.S.A. 104. 18866-18870 (2007). doi:10.1038/nature06591

2. P. Friedlingstien et al. Climate-carbon cycle feedback analysis: results from the C4MIP model intercomparison. J. Clim. 19. 3337-3353 (2006). doi:10.1038/nature06591

3. M. Heimann, M. Reichstein. Terrestrial ecosystem carbon dynamics and climate feedbacks. Nature 451. 289-292 (2008). doi:10.1038/nature06591

4. P. Ciais et al. "Carbon and other biogeochemical cycles" in Climate change 2013: the physical science basis. Working group I contribution to the IPCC fifth assessment report (AR5). (IPCC, Geneva, Switzerland, 2013). doi:10.1017/CBO9781107415324 
5. E. A. Davidson, I. A. Janssens Temperature sensitivity of soil carbon decomposition and feedbacks to climate change. Nature 440. 165-173 (2006). doi:10.1038/nature04514

6. M.W.I. Schmidt et al. Persistence of soil organic matter as an ecosystem property. Nature $\mathbf{4 7 8}$. 49-56 (2011). doi:10.1038/nature10386

7. M. Lu et al. Responses of ecosystem carbon cycle to experimental warming: a meta-analysis. Ecology. 94, 726-38 (2013). doi: 10.1890/12-0279.1

8. J.M. Melillo, D.W. Kicklighter, A.D. McGuire, W.T. Peterjohn, K.M. Newkirk. "Global change and its effects on soil carbon stocks" in Report of the Dahlmem workshop on the role of nonliving organic matter in the earth's carbon cycle, R. Zepp, C. Sonntag, Eds. (Wiley, 1995).doi:10.1002/aheh.19960240519

9. J.M. Melillo et al. Soil warming and carbon-cycle feedbacks to the climate system. Science 298. 2173-2776 (2002). doi:10.1126/science.1074153

10. J.M. Melillo et al. Soil warming, carbon-nitrogen interactions, and forest carbon budgets. Proc. Natl. Acad. Sci. U.S.A. 108. 9508-9512 (2011). doi:10.1073/pnas.1018189108

11. A.P. Sokolov et al. Consequences of considering carbon-nitrogen interactions on the feedbacks between climate and the terrestrial carbon cycle. J Clim. 21. 3776-3796 (2008). doi:10.1175/2008JCLI2038.1

12. P.E. Thornton et al. Carbon-nitrogen interactions regulated climate-carbon cycle feedbacks: results from an atmosphere-ocean general circulation model. Biogeosciences 6. 20992120 (2009). doi:10.5194/bg-6-2099-2009

13. W.T. Peterjohn, J.M. Melillo, F.P.Bowles, P.A. Steudler. Soil warming and trace gas fluxes: Experimental design and preliminary flux results. Oecologia 93:18-24 (1993). doi:10.1007/BF00321185

14. W.T. Peterjohn et al. The response of trace gas fluxes and $\mathrm{N}$ availability to elevated soil temperatures. Ecol. Appl. 4: 617-625 (1994). doi:10.2307/1941962

15. C.E. Hicks Preis, C. Castanha, R.C. Porras, M.S. Torn. The whole-soil carbon flux in response to warming. Science 355, 1420-1423 (2017) 
16. Y. Luo, S. Wan, D. Hui, L.L. Wallace. Acclimatization of soil respiration to warming in a tall grass prairie. Nature 413, 622-625 (2001).

17. S.D. Frey, R. Drijber, H. Smith, J.M. Melillo. Microbial biomass, functional capacity, and community structure after 12 years of soil warming. Soil Biol. Biochem. 40: 2904-2907 (2008). doi:10.1016/j.soilbio.2008.07.020

18. M.A. Bradford et al. Thermal Adaptation of Soil Microbial Respiration to Elevated Temperature. Ecology Letters. 11: 1316-1327. doi:10.1111/j.14610248.2008.01251.x.(2008). doi:10.1111/j.1461-0248.2008.01251.x

19. G. Pold, A.S. Grandy, J.M. Melillo, K.M. DeAngelis. Changes in substrate availability drive carbon cycle response to chronic warming. Soil Biol. Biochem. 110. 68-783. (2017). doi:10.1016/j.soilbio.2017.03.002.

20. K.M. DeAngelis, et al. Long-term forest soil warming alters microbial communities in temperate forest soils. Front. Microbiol. 6. 104 (2015). doi:10.3389/fmicb.2015.00104

21. G. Pold, J.M. Melillo, K.M. DeAngelis. Two decades of warming increases diversity of a potentially lignolytic bacterial community. Front. Microbiol. 6480 (2015) doi:10.3389/fmicb.2015.00480

22. G. Pold et al. Long-term warming alters carbohydrate degradation potential in temperate forest soils. Appl. Environ. Microbiol. 82. 6518-6530. (2016). doi:10.1128/AEM.0201216

23. S.D. Frey, J. Lee, J.M. Melillo, J. Six. The temperature response of microbial efficiency and its feedback to climate. Nat. Clim. Chang. 3.395-398 (2013). doi:10.1038/nclimate1796

24. S.D. Allison, M.D. Wallenstein, M.A. Bradford. Soil-carbon response to warming dependent on microbial physiology. Nature Geoscience 3, 336-340 (2010).

25. S.E. Trumbore. Potential Responses of Soil Organic Carbon to Global Environmental Change. Proc. Natl. Acad. Sci. U.S.A. 94: 8284-8291 (1997). doi:10.1073/pnas.94.16.8284

26. T. W. Crowther et al. Quantifying global soil carbon losses in response to warming. Nature 540, 104-108 (2016). 
27. E.G. Jobbágy, R.B. Jackson. The vertical distribution of soil organic carbon and its relation to climate and vegetation. Ecol. Appl. 10, 423-436 (2000). doi:10.1890/10510761(2000)010\%5B0423:TVDOSO\%5D2.0.CO;2

28. J. Rousk, P.W. Hill, D.L. Jones Priming of the decomposition of ageing soil organicmatter: concentration dependence and microbial control. Functional Ecology 29, 285-296 (2015) doi: $10.1111 / 1365-2435.12377$

29. C. Le Quéré et al. Global Carbon Budget 2016. Earth Syst. Sci. Data, 8, 605-649 (2016). doi:10.5194/essd-8-605-2016.

30. R.S. DeFries, C.B.,Field, I. Fung, G.J. Collatz, L. Bounoua. Combining satellite data and biogeochemical models to estimate global effects of human-induced land cover change on carbon emissions and primary productivity. Global Biogeochemical Cycles 13: 803815 (1999). doi: 10.1029/1999GB900037..

31. E. Boose, E. Gould. Shaler Meteorological Station at Harvard Forest 1964-2002. Harvard Forest Data Archive: HF000. (1999). Accessed 6/1/2017.

32. E. Boose. Fisher Meteorological Station at Harvard Forest since 2001. Harvard Forest Data Archive: HF001 (2001). Accessed 6/1/2017.

33. R. D. Bowden, J.M. Melillo, P.A. Steudler and J.D. Aber. Effects of nitrogen additions on annual nitrous oxide fluxes from temperate forest soils in the northeastern United States. Journal of Geophysical Research 96: 9321-9328, (1991) doi: 10.1029/91JD00151.

34. R. Setia, S.L. Verma, P. Marschner. Measuring microbial biomass carbon by direct extraction-comparison with chloroform fumigation-extraction. European Journal of Soil Biology 53. 103-106 (2012). doi:10.1016/j.ejsobi.2012.09.005

35. A. R. Contosta, S. D. Frey, A. B. Cooper. Seasonal dynamics of soil respiration and N mineralization in chronically warmed and fertilized soils. Ecosphere 2, Article 36. (2011). 
258 Acknowledgments: This research has been supported by grants from the Department of Energy

259 - DE-SC0010740; DOE DE-SC0016590: and the National Science Foundation - DEB 1237491

260 (LTER) ; DEB 1456528 (LTREB).

261

262 We thank the team of scientists who worked with us on the study over the past 26 years,

263 including T. Ahrens, C. Baldino, J. Blanchard, M. Bradford, L. Burrows, A. Burton, S. Butler, C.

264 Catricala, R. Hanifin, T. Hill, J. Johnson, H. Lux, J. Mohan, S. Morrisseau, K. Newkirk, W.

265 Peterjohn, A. Ricca, L. Scott, R. Smith, P.Steudler, C. Vario.

266

267 Datasets pertaining to this study are available on the Harvard Forest Online Data Archive

268 (http://harvardforest.fas.harvard.edu/harvard-forest-data-archive), datasets hf005 and hf171.

269

270

271

272

273

274

275

276 


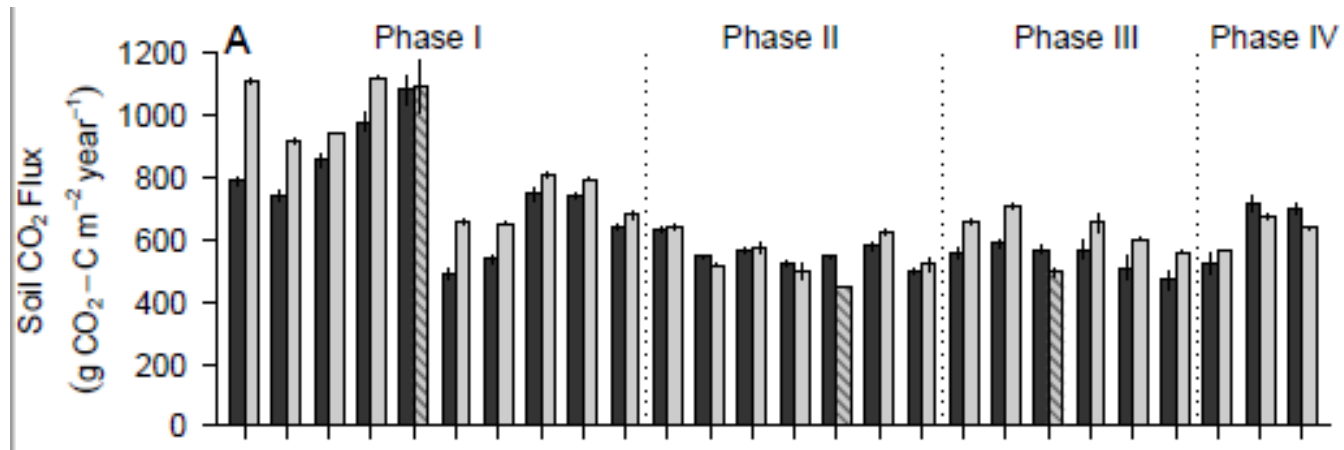

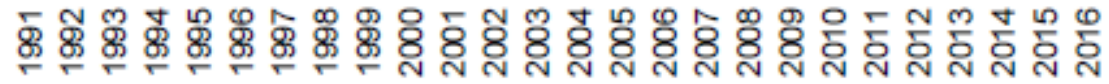

Fig. 1. Effect of soil warming on soil respiration over 26 years. (A) Annual soil $\mathrm{CO} 2$ emissions from the control plots (black bars) and heated plots (gray bars). Asterisks denote years when the heated and control plots are significantly different (paired-sample t tests or Wilcoxon signed-rank tests as appropriate, $n=(6,6),{ }^{*} P<0.05$; see supplementary materials). Hatched bars denote years when the heating system was inactive for the majority of the growing season. Error bars denote SEM $(n=6)$. (B) Four-year rolling mean increase in soil CO2 emissions in the heated plots relative to the control plots, excluding years when the heating system was inactive for the majority of the growing season. Error bars denote SEM derived from propagating SE estimates from (A) through the operations necessary to produce (B). See fig. S4 for annual changes in soil $\mathrm{CO} 2$ emissions in the heated plots relative to the control plots. 


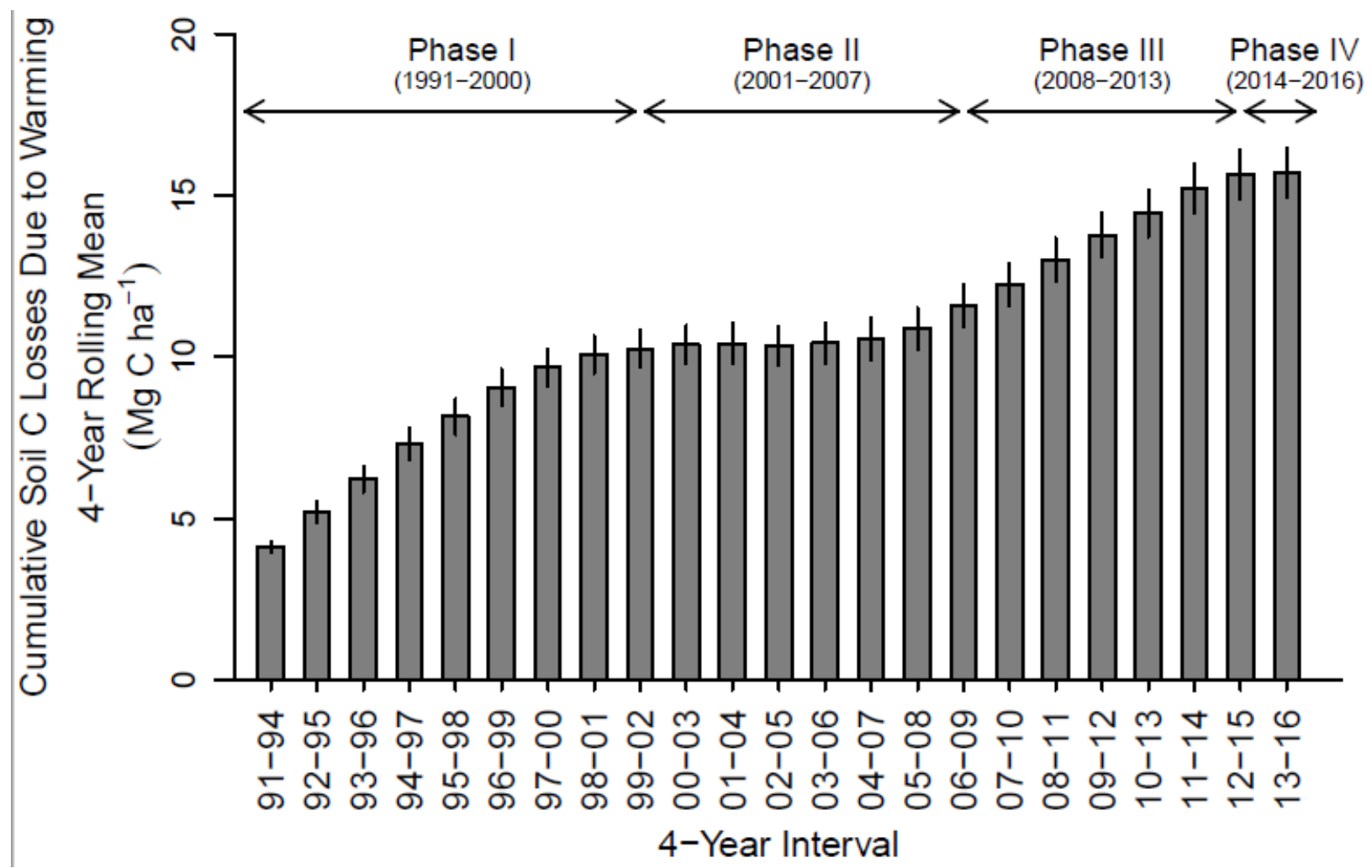

Fig. 2. Four-year rolling mean cumulative modeled soil carbon losses from the full soil

291 profile over 26 years of soil warming in the heated plots relative to the control plots.

292 Relative soil carbon losses are calculated as the difference in heterotrophic soil respiration

293 between the heated plots and the control plots. Error bars denote SEM, calculated for the heated

$294(\mathrm{n}=6)$ and control $(\mathrm{n}=6)$ plots for each year and propagated through the necessary operations to 295 produce this figure. 

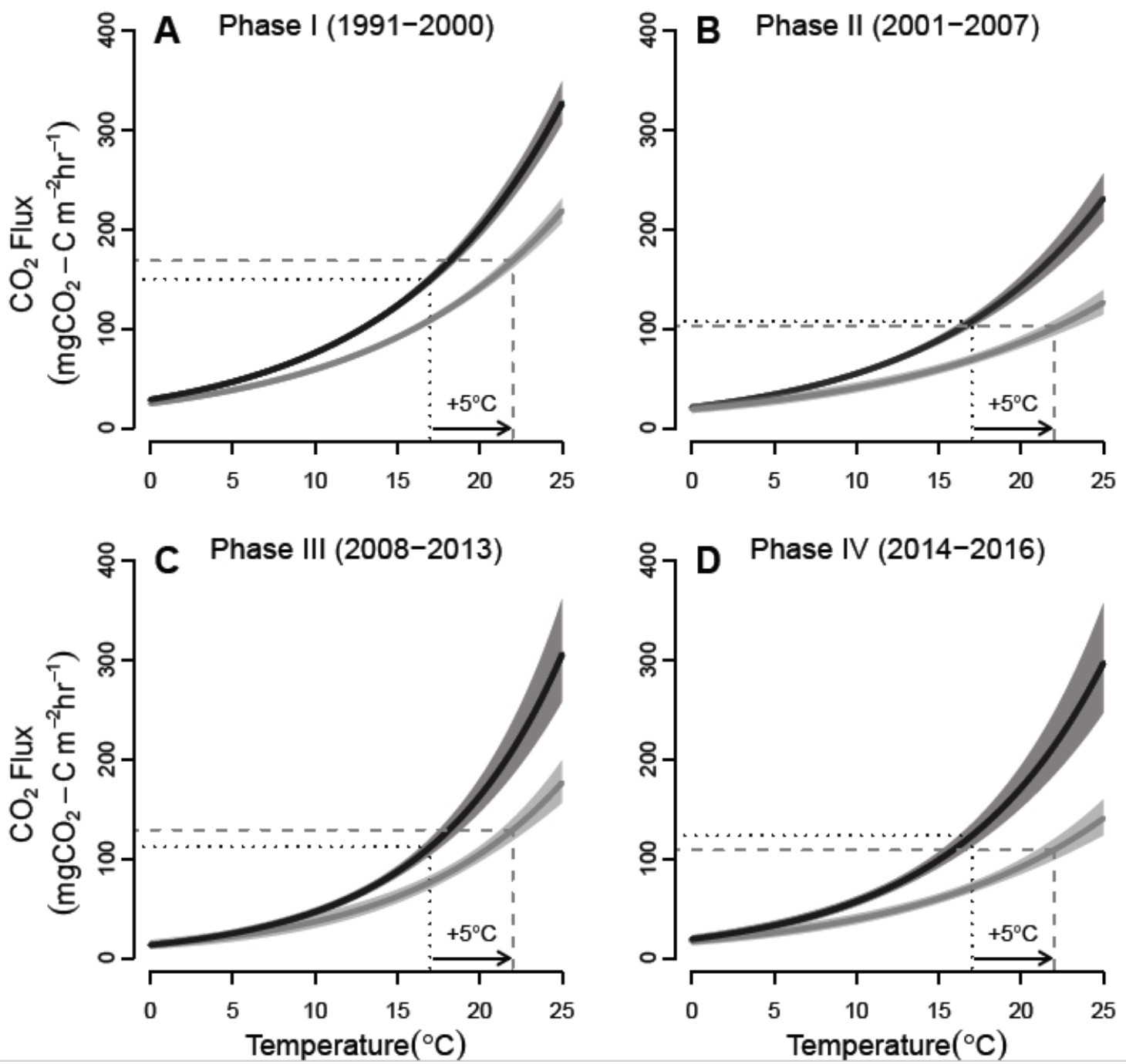

Fig. 3. Relationship between soil respiration and soil temperature in the heated and control plots during each phase of the experiment. We modeled this relationship as an exponential function of soil temperature: respiration $=a[\exp (b \times$ temperature $)]$, where $a$ is respiration rate at $0^{\circ} \mathrm{C}$ and $\mathrm{b}$ is temperature sensitivity of respiration. Solid dark gray curves represent control plot models; solid light gray curves represent heated plot models. For the purposes of this figure, each model was fitted to all respiration data collected within the phase. Shaded areas around each curve represent normal-based 95\% confidence intervals. Dashed lines illustrate predicted soil respiration during each phase when the control plots are $17^{\circ} \mathrm{C}$ and the heated plots are $22^{\circ} \mathrm{C}$, the respective summer modal temperatures of the control and heated plots over the course of the experiment. 


\begin{tabular}{|c|c|c|c|c|c|c|}
\hline & $\begin{array}{l}\text { Orga } \\
\% \\
\text { change }\end{array}$ & $\begin{array}{l}\text { anic } \\
\text { Effect } \\
\text { size }\end{array}$ & $\begin{array}{l}\text { Mine } \\
\% \\
\text { change }\end{array}$ & $\begin{array}{l}\text { eral } \\
\text { Effect } \\
\text { size }\end{array}$ & Method (units) & Ref \\
\hline \multicolumn{7}{|l|}{ Phase I (1991-2002) } \\
\hline \multicolumn{7}{|l|}{ Phase II (2001-2007) } \\
\hline Depletion of labile soil C pool & $-25 \%$ & -3.3 & $-25 \%$ & -3.5 & DOC $^{\text {a }}$ (ug C g ${ }^{-1}$ soil), seasonal median & 18 \\
\hline Reduction in microbial use of simple $\mathrm{C}$ & $-33 \%$ & -4.3 & $-57 \%$ & -5 & $\operatorname{SIR}^{\mathrm{b}}\left(\mathrm{ug} \mathrm{C} \mathrm{g}^{-1}\right.$ soil day $\left.{ }^{-1}\right)$, seasonal median & 18 \\
\hline Reduction in microbial use of simple C & $-44 \%$ & -3.4 & $-44 \%$ & -3.4 & $\operatorname{SIR}^{\mathrm{b}}\left(\mathrm{ug} \mathrm{C} \mathrm{g}^{-1}\right.$ soil day $\left.{ }^{-1}\right)$ & 17 \\
\hline Reduction of microbial biomass & $-74 \%$ & -3.6 & $-12 \%$ & -0.6 & $\mathrm{CFE}^{\mathrm{c}}$ (ug C g ${ }^{-1}$ soil), seasonal median & 18 \\
\hline Reduction of microbial biomass & $-26 \%$ & -3.5 & $-27 \%$ & -6.1 & Lipid P (nmol g ${ }^{-1}$ soil) & 17 \\
\hline Relative loss of fungal biomass & $-19 \%$ & -3.0 & $-28 \%$ & -3.8 & Lipid $P$ (nmol g ${ }^{-1}$ soil), fungi & 17 \\
\hline Decline in fungal:bacterial ratio & $-14 \%$ & -5.0 & $-23 \%$ & -8.5 & Lipid P (nmol g ${ }^{-1}$ soil) & 17 \\
\hline \multicolumn{7}{|l|}{ Phase III (2008-2013) } \\
\hline Restructuring of microbial community & $3.5 \%$ & 2.1 & $3 \%$ & 1.2 & Phylogenetic diversity (Shannon's H) & 20 \\
\hline $\begin{array}{l}\text { Shift towards more oligotrophic } \\
\text { community }\end{array}$ & $-5.0 \%$ & -1.2 & $2 \%$ & 0.4 & rRNA copy number & 20 \\
\hline $\begin{array}{l}\text { Acceleration of microbial reduction of } \\
\text { lignin }\end{array}$ & $-6.0 \%$ & -0.1 & $372 \%$ & 1.5 & Oxidative $\mathrm{EEA}^{\mathrm{d}}\left(\mu \mathrm{mol}\right.$ cells $\left.{ }^{-1} \mathrm{hr}^{-1}\right)$ & 21 \\
\hline \multirow{2}{*}{$\begin{array}{l}\text { Reduction of microbial biomass } \\
\text { Reduction of temperature sensitivity of } \\
\text { microbial efficiency for recalcitrant } \\
\text { substrates }\end{array}$} & $-23 \%$ & -1.6 & $-16 \%$ & -1.4 & Lipid P (nmol g ${ }^{-1}$ soil) & 20 \\
\hline & n.d. & n.d. & $-31 \%$ & -5.6 & $\begin{array}{l}{ }^{13} \mathrm{C} \text {-Phenol Utilization } \\
\left(\mathrm{C}_{\text {growth }} \mathrm{C}_{\text {metabolized }}{ }^{-1}{ }^{\circ} \mathrm{C}^{-1}\right)\end{array}$ & 23 \\
\hline $\begin{array}{l}\text { Alteration of fungal:bacterial ratio of C- } \\
\text { degrading genes }\end{array}$ & $31 \%$ & 1.0 & $-11 \%$ & -0.8 & Fungal:bacterial CAZy gene ratio & 22 \\
\hline Decreased lignin relative abundance & $-24 \%$ & -1.2 & $-29 \%$ & -0.9 & pyGCMS ${ }^{e}$ Lignin \% fraction of SOM ${ }^{q}$ ) & $\mathrm{TS}^{\mathrm{h}}$ \\
\hline \multicolumn{7}{|l|}{ Phase IV (2014-2016) } \\
\hline Reduction in microbial biomass & $-40 \%$ & * & $-40 \%$ & * & $\operatorname{DCE}^{\dagger}\left(\mu \mathrm{g} \mathrm{N} \mathrm{g}^{-1}\right.$ soil) & $\mathrm{TS}^{\mathrm{h}}$ \\
\hline Reduction in microbial biomass & $-25 \%$ & -0.9 & $-20 \%$ & -0.7 & Lipid P (ng g ${ }^{-1}$ soil), seasonal median & 19 \\
\hline Decreased lignin relative abundance & $-17 \%$ & -0.8 & $-53 \%$ & -1.3 & pyGCMS ${ }^{e}$ (Lignin $\%$ fraction of $\mathrm{SOM}^{9}$ ) & 19 \\
\hline
\end{tabular}

Table 1. Changes observed in soil $\mathrm{C}$ pools and the microbial community in response to soil warming of $5^{\circ} \mathrm{C}$ above ambient in phases II to IV of the 26-year experiment. Percent change is

313 based on observed means in heated plots relative to controls. Effect size is calculated by

314 Cohen's D test using pooled standard deviation. Percent changes smaller than $10 \%$ and effect

315 sizes smaller than 2 (equivalent to a shift of two standard deviations) are in italics; n.d., not

316 determined. DOC, dissolved organic carbon; SIR, substrate-induced respiration; CFE, chloroform

317 fumigation extraction; EEA, extracellular enzyme activity; CAZy, carbohydrate-active enzymes;

318 pyGCMS, pyrolysis gas chromatography-mass spectrometry; DCE, direct chloroform extraction;

319 SOM, soil organic matter. For phases II to IV, "reduction in microbial biomass" refers to a

320 within-phase decrease in the microbial biomass in the heated soils relative to the control soils

321 measured during that phase. An asterisk indicates that within-treatment plot-to-plot variability

322 could not be measured and effect size could not be determined because measurements were

323 made on soil samples bulked by treatment. No measurements were made of changes in

324 microbial responses to warming during phase I. 